\title{
EMBOLIZATION IN RECURRENT SOFT TISSUE AMELOBLASTOMA EXCISION OF THE MANDIBLE
}

Agus Widodo*, Masykur Rahmat*, Rahardjo**, Poerwati Soetji**

${ }^{*}$ Residen Bedah Mulut dan Maksilofasial Universitas Gadjah Mada

** Departemen Bedah Mulut dan Maksilofasial Universitas Gadjah Mada

Correspondence: widodoagus06051981@gmail.com

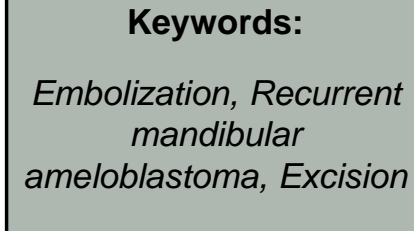

\section{PENDAHULUAN}

Ameloblastoma merupakan tumor odontogenik yang paling umum ditemui dan mewakili kira-kira $10 \%$ dari seluruh tumor yang ditemukan di area mandibula dan maksila. Insidensinya sangat bervariasi pada kelompok ras yang berbeda. Penelitian menunjukkan bahwa ameloblastoma lebih sering terjadi pada kelompok ras keturunan Afrika daripada kulit putih. 1 Insidensi secara global diperkirakan sekitar 0,5 kasus per satu juta penduduk per tahun, dan sebagian besar kasus terdiagnosis pada pasien kelompok umur 30 hingga 60 tahun.2

Disebabkan sifat agresifnya secara lokal dan tingkat rekurensi yang tinggi setelah tindakan, perawatan ameloblastoma masih menjadi perdebatan hingga saat ini. Tindakan kuretase menurut laporan mempunyai angka rekurensi sebesar $50 \%$, tindakan reseksi marginal $15 \%$, sedang reseksi yang lebih radikal hasilnya lebih memuaskan. Tindakan reseksi memiliki tingkat rekurensi yang paling rendah, maka tindakan reseksi dapat dikatakan sebagai tindakan definitif untuk kasus ameloblastoma. Jenis reseksi mandibula yang digunakan pada ameloblastoma adalah reseksi marginal, reseksi segmental, reseksi parsial (hemimandibulektomi) dan reseksi total (total mandibulektomi) tergantung dari ukuran dan perluasan tumor.3

Rekurensi pada jaringan lunak pasca tindakan reseksi yang dilaporkan oleh Olaitan 
sekitar 19\%, sedangkan menurut Arotiba sekitar 13,3\% dari 30 kasus yang dikerjakan.4,5 Rekurensi ameloblastoma pada jaringan lunak setelah tindakan radikal dilaporkan dalam jangka waktu setelah 5 tahun, 25 tahun, bahkan 49 tahun setelah tindakan. Tingkat rekurensi ameloblastoma pada jaringan lunak ditentukan oleh margin pembedahan yang tidak adekuat dan ameloblastoma multikistik lebih besar tingkat rekurensinya dibandingkan

dengan tipe unikistik. Prognosis ameloblastoma ditentukan oleh usia pasien, ukuran tumor, perluasan tumor, lokasi tumor, dan tipe histologisnya.6

\section{LAPORAN KASUS}

Perempuan usia 32 tahun datang ke RSUP Dr.Sarjito dengan keluhan terdapat pembengkakan disertai nyeri pada pipi sebelah kiri dengan riwayat 14 tahun pasca tindakan hemimandibulektomi karena ameloblastoma multikistik. Pasien datang sudah membawa hasil biopsi dari rumah sakit sebelumnya yaitu ameloblastoma tipe folikuler dan tidak ada keganasan. Tiga tahun setelah operasi pembengkaan mulai muncul kembali dan bertambah besar meluas ke pipi tanpa dilakukan tindakan. Pemeriksaan objektif kondisi umum baik,
Embolisasi adalah prosedur invasif non bedah dengan cara menyuntikkan bahan embolan ke dalam pembuluh darah yang menginervasi area tumor.7 Embolisasi menjadi terapi yang sangat berguna dengan berbagai tujuan diantaranya embolisasi dalam bidang onkologi untuk mengurangi gejala, mencegah dan mengurangi perdarahan durante operasi, meningkatkan angka bertahan hidup dan kualitas hidup.8

Tujuan laporan kasus ini adalah melaporkan tindakan embolisasi pada kasus ameloblastoma rekuren jaringan lunak yang berukuran besar dengan hipervaskularisasi dengan resiko perdarahan intraoperatif.

hasil pemeriksaan penunjang dalam batas normal. Kondisi ekstra oral tampak pembengkaan solid dengan ukuran $10 \times 10 \mathrm{~cm}$ warna kemerahan. Pemeriksaan intra oral terdapat masa dengan bentuk berdungkul-dungkul dengan warna kemerahan. Pemeriksaan penunjang CT-Scan kontras mendukung ameloblastoma, dan sudah mengekspansi tulang zygoma sehingga tampak melebar.
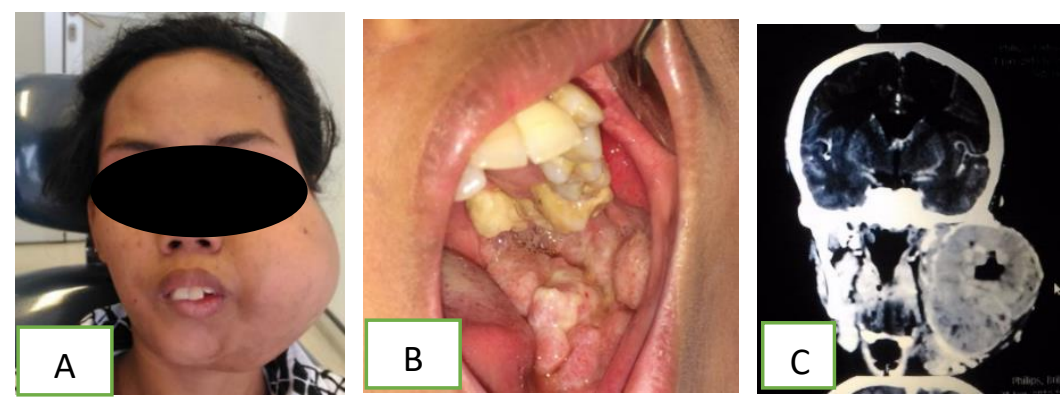

Gambar 1. (A) Foto klinis ekstra (B) Foto klinis intra oral (C) Foto CT San kontras potongan koronal

Sebelum dilakukan tindakan eksisi tumor didahului dengan tindakan arteriografi dan embolisasi oleh bagian radiologi intervensi dengan tujuan untuk mengurangi perdarahan selama operasi. Embolisasi dilakukan pada pembuluh darah yang mensuplai massa tumor yaitu pada pangkal arteri maksilaris sinistra cabang arteri alveolaris inferior dan arteri fasialis sinistra dengan bahan gelfoam dan PVA. 

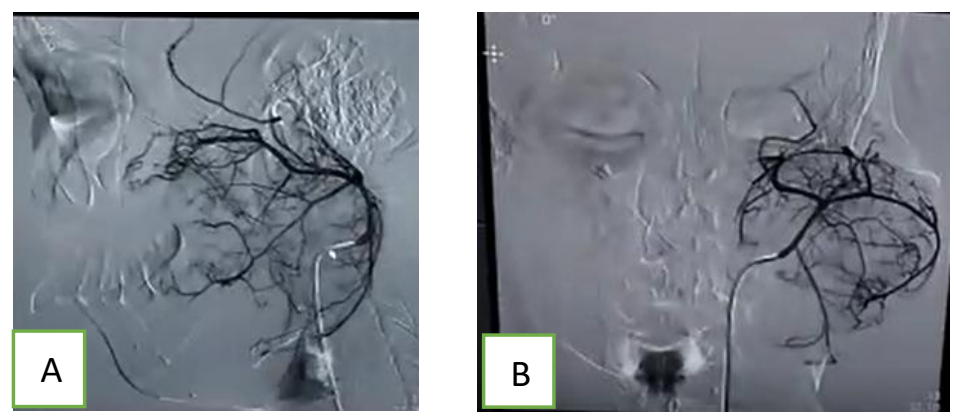

Gambar 2. (A) Arteriografi dan embolisasi dari samping (B) Arteriografi dan embolisasi dari depan

Kondisi klinis pasien setelah dilakukan tindakan embolisasi $\mathrm{H}-3$ sampai dengan $\mathrm{H}-1$ sebelum operasi tampak ukuran tumor menjadi lebih kecil, area kemerahan pada intra oral menjadi berwarna pucat.
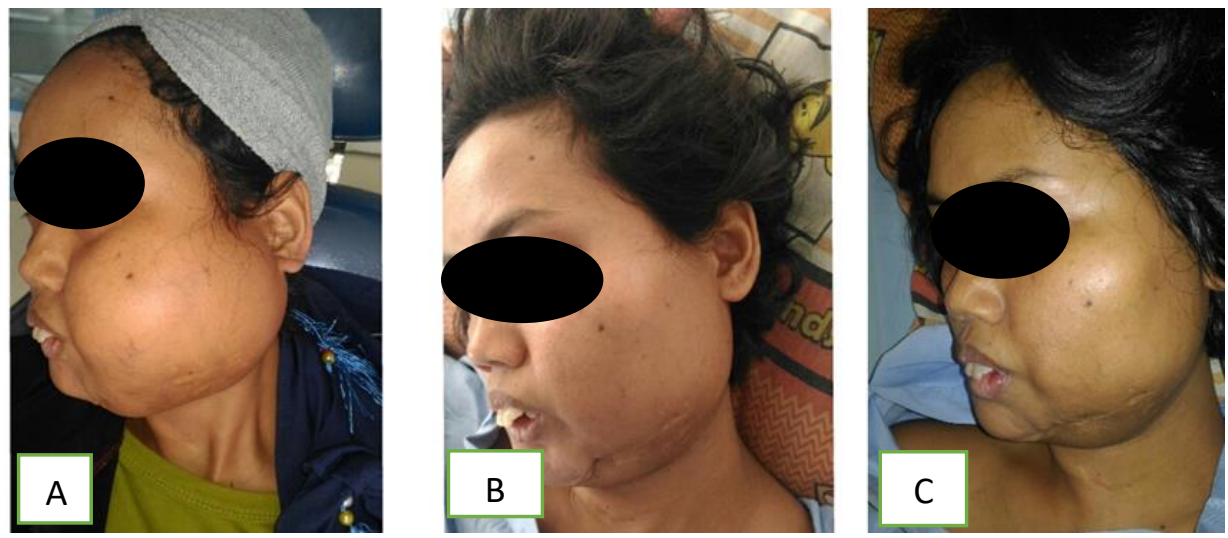

Gambar 3. (A) Foto klinis lateral sebelum embolisasi (B) Pasca embolisasi, H-2 sebelum eksisi (C) H-1 sebelum eksisi

Tindakan eksisi tumor dilakukan setelah hari ke-3 pasca embolisasi, dengan teknik lip split untuk mencapai akses tumor lebih jelas. Perdarahan selama operasi pada tindakan eksisi yang dilakukan sekitar $250 \mathrm{ml}$ dan tidak ada tambahan tranfusi darah.
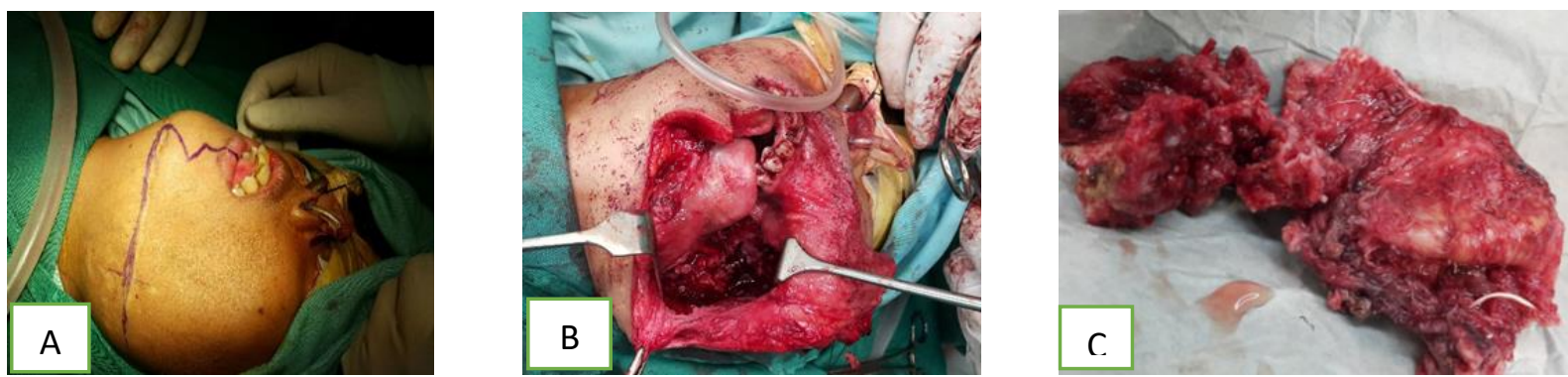

Gambar 4. (A) Pola incisi lip split (B) Durante operasi (C) Massa tumor

Evaluasi pasca operasi setelah 3 bulan kondisi umum pasien baik, ekstra oral tampak asimetris, terdapat defek pasca operasi, kondisi intra oral baik, tidak tampak adanya rekurensi, tidak ada gangguan penelanan. Pemeriksaan patologi anatomi didapatkan hasil ameloblastoma multikistik tipe folikuler dan sebagian tipe pleksiform. Hasil CT Scan dengan kontras pasca tindakan eksisi menunjukan tidak tampak residu maupun residif ameloblastoma 

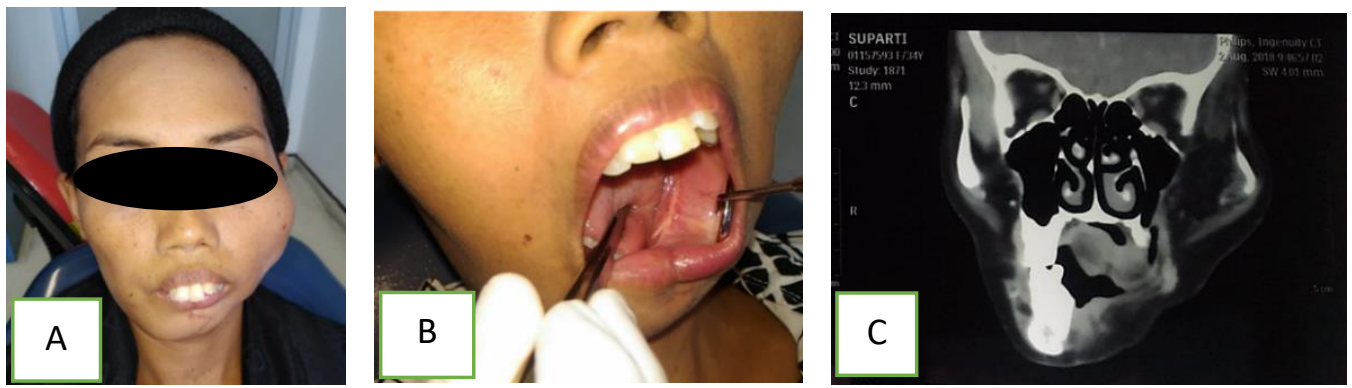

Gambar 5. (A) Foto klinis ekstra oral (B) Foto klinis intra oral (C) CT Scan kontras potongan koronal

\section{DISKUSI}

Ameloblastoma pada kasus ini muncul kembali pada jaringan lunak setelah 3 tahun pasca hemimandibulektomi dan tidak dilakukan tindakan dalam jangka waktu lama sehingga massa yang besar mengekspansi tulang zigoma, hal ini lebih cepat dari waktu rata-rata kasus yang sudah dilaporkan yaitu setelah 5 tahun pasca tindakan radikal. Kondisi ini bisa disebabkan kurang bersihnya area operasi terutama jaringan lunak yang telah terjadi infiltrasi sel tumor pada jaringan lunak, tidak dapat dideteksi secara klinis maupun radiografis, serta tipe ameloblastoma multikistik yang mempunyai angka rekurensi yang lebih tinggi.9

Tumor pada mukosa bukal menunjukkan telah terjadi rekurensi ameloblastoma di jaringan lunak, hal ini terjadi karena dinding tumor sudah tidak utuh dan perluasan tumor sudah meluas hingga sel-sel tumor berinfiltrasi ke jaringan lunak. Perawatan terbaik untuk kasus ameloblastoma rekuren pada jaringan lunak adalah eksisi dengan mengambil seluruh jaringan patologis dengan melibatkan sedikit jaringan sehat disekitarnya. 10 Tindakan eksisi yang dilakukan pada kasus ini dengan pendekatan lip split sehingga lapang pandang operasi lebih jelas dan struktur vital dapat lebih aman. Pasien yang telah menjalani reseksi ameloblastoma dianjurkan untuk melakukan evaluasi secara berkala sampai 5 sampai dengan
10 tahun dengan pemeriksaan klinis dan radiologis. 11

Arteriografi dan embolisasi dilakukan 24-72 jam sebelum tindakan eksisi ameloblastoma rekuren jaringan lunak. Embolisasi tumor dilakukan melalui pendekatan transarterial dengan kateterisasi selektif ke cabang pembuh darah yang memberikan aliran darah ke tumor dengan menggunakan berbagai agen embolan.12 Embolisasi pada kasus ini menggunakan gelfoam dan PVA yang dilakukan oleh seorang ahli radiologi intervensi dengan melakukan penyumbatan pembuluh darah yang menginervasi tumor yaitu fasialis sinistra dan arteri maksilaris sinistra pada cabang pertama dari arteri alveolaris inferior sinistra. Embolisasi dilakukan sebelum operasi pada kasus tumor dengan hipervaskularisasi dan ukuran yang besar untuk mengurangi perdarahan selama operasi dan dapat mengurangi kehilangan darah sekitar $60 \%$ selama operasi berlangsung. Embolisasi preoperatif pada kasus ameloblastoma rekuren jarang dilakukan sebab ameloblastoma yang muncul kembali biasanya masih berukuran kecil dan diketahui secara dini pada waktu kontrol rutin. 13

Embolisasi pada kasus ameloblastoma rekuren bertujuan untuk membuat iskemia dan nekrosis di pusat tumor, dengan menyumbat pembuluh darah yang menjadi feeding vessel pada ameloblastoma jaringan lunak. Embolisasi kasus ini 
dilakukan pada pangkal arteri maksilaris sinistra pada cabang pertama arteri alveolaris inferior dan fasialis sinistra sehingga tumor tidak mendapat suplai darah. Kondisi ini akan menyebabkan tumor menjadi nekrosis dan ukuran menyusut sehingga jaringan sehat yang berbatasan dengan tumor akan menjadi lebih jelas. 10

Keuntungan embolisasi sebelum operasi adalah pengurangan kehilangan darah intraoperatif, penyumbatan pembuluh darah arteri yang tidak dapat diakses pada pembedahan, penurunan waktu operasi, dan peningkatan visualisasi, serta memungkinkan untuk identifikasi dan perlindungan struktur yang berdekatan mengakibatkan pengurangan komplikasi pembedahan secara keseluruhan.10 Kebanyakan pasien mengalami rasa sakit yang berhubungan dengan iskemia setelah embolisasi. Tingkat nyeri cenderung meningkat dengan embolisasi pada pembuluh darah yang lebih distal karena infark jaringan mungkin terjadi. Intensitas nyeri bervariasi antar individu, pasien dikontrol dengan analgetik dan biasanya digunakan opiat untuk penanganan nyerinya. Kehilangan darah selama operasi pada kasus ini sekitar $250 \mathrm{ml}$ sehingga pasien tidak memerlukan tranfusi.

\section{KESIMPULAN}

Tindakan embolisasi preoperatif pada pasien ameloblastoma rekuren jaringan lunak ukuran besar dapat mengecilkan ukuran tumor dan menurunkan kehilangan darah intraoperatif.

\section{DAFTAR PUSTAKA}

1. Anderson, L., Kahnberg, K.E., Pogrel, A., Oral and Maxillofacial Surgery, 2012, Wiley.11091125.

2. Mc Clary, A.C., West, R.B., Pollack, J.R., Fisbein, N.J., Sunwool, J., Colevas, A.D.,
Sirjani, D., Ameloblastoma: a clinical review and trends in management, Eur Arch Otorhinolaryngol, 2015, DOI 10.1007/s00405015-3631-8.

3. Neville, B.W., Damn, D.D., Allen, C.M. Bouqout, Oral and Maxillofacial Pathology 2nd ed., 2002, Philadelphia. WB Saunders Co. p. 610-615.

4. Olatian, A.A., Arole, G., Adekeye, E.O., Recurrent ameloblastoma of the jaws: A followup study, 1998, Int J Oral Maxillofac Surg;27:456-460.

5. Arotiba, J.T., Ogunbiyi, J.O., Obiechina, A.E., Odontogenic tumours: a 15 year review from Ibadan Nigeria, 1997, Br J OralMaxillofac Surg ; 35: 363-7.

6. Xavier, S.P., Faria, A.C., Mello, F., Silva, E.R., Santana, S.T., Recurrence of ameloblastoma in soft tissue, 2013, J Craniofac Surg;24:1866-7.

7. Xianli, L.V., Zhongxue,W., Jiang, C., Li,Y., Yang, X., Zhang, Y., Zhang, N., Complication risk of endovascular embolization for cerebral arteriovenous malformation, 2010, Eur J Radiol;09;024.

8. Blinkert, C.A., 2002, Embolization tools and techniques, Applied Radiology, 2002; p 55-64.

9. Fregnani , E.R., Cruz P., Almeida O.P., Kowalski, L.P., Soares, F.A., Abreu, A.F., Clinicopathological study and treatment outcomes of 121 cases of ameloblastomas, 2010, Int J Oral Maxillofac Sur ; 39: 145-149.

10. Mann, W.J., Jecker, P., Amedee, R.G., Juvenile angiofibromas: changing surgical concept over the last 20 years, 2004, Laryngoscope; 114: 291-3.

11. Hertdog,D., Isaac, Ameloblastoma of the jaws: A critical reappraisal based on a 40-years single institution experience, 2009, Oral Oncology 46: 61-64.

12. Danesi, G., Panciera, D.T., Harvey, R.J., Agostinis, C., Juvenile nasopharyngeal angiofibroma: evaluation and surgical management of advanced disease, 2008, Otolaryngol Head Neck Surg; 138:581-6.

13. Gemmete, J.J., Chaudhary, N., Pandey, A., Gandhi, D., Sullivan, S.E., Marentette, L.J., Chepea, D.B,, Ansari, S.A., Usefulness of percutaneously injected ethylenevinyl alcohol copolymer in conjunction with standard endovascular embolization techniques for preoperative devascularization of hypervascular head and neck tumors: technique, initial experience, and correlation with surgical observations, 2008, AJNR Am J Neuroradiol; 31: 961-6. 